\title{
BIOLOGICAL TREATMENT OF LANDFILL LEACHATE: EFFORD LANDFILL, HAMPSHIRE, UK - A CASE STUDY
}

\author{
Steve Last \\ Jonty Olufsen \\ Howard Robinson \\ Enviros Consulting, United Kingdom
}

\begin{abstract}
Demand for of on-site treatment schemes that are capable of treating landfill leachates to high standards has grown substantially during the last two decades. Increasingly, plants are being required to discharge high quality effluents directly into surface watercourses, or to provide a high degree of treatment prior to discharge into the public sewerage system. This trend is certain to continue - primarily driven in the United Kingdom in recent months by the requirements of the EU IPPC Directive, which demands the application of Best Available Techniques (BAT), and by the EU Water Framework Directive.
\end{abstract}

Aerobic biological treatment of leachate from domestic landfills has widely been shown to be the most appropriate, reliable and successful treatment technique to consistently meet stringent discharge constraints with minimal operator input. The cost of this technology is also often favourable, when compared with alternative processes. More than 50 plants of this type are currently operational in the United Kingdom, making it by far the most widely adopted on-site treatment technology, and many other examples exist overseas.

This paper provides a detailed case study of the design, construction and commissioning of a biological, Sequencing Batch Reactor (SBR) leachate treatment plant for Hampshire County Council, at Efford Landfill Site in the New Forest in Hampshire, UK.

Since plant commissioning was completed by the authors during early 2003, extensive and detailed monitoring data have been collected. These are presented for the plant, which is capable of treating up to $150 \mathrm{~m}^{3} /$ day of strong methanogenic leachate (ammoniacal-N from 600$1000 \mathrm{mg} / \mathrm{l})$, and are compared with treatment performances achieved at other full-scale leachate treatment plants. The paper shows $\mathrm{BOD}_{5}$ and ammoniacal-N removal efficiencies in excess of $99 \%$.

Results also show the efficiency of polishing treatment in a reed bed, before discharge of final effluent to public sewer. 
Kalmar ECO-TECH'05 and

The Second Baltic Symposium on Environmental Chemistry

KALMAR, SWEDEN, November 28-30, 2005

\section{KEYWORDS}

Landfill; Leachate; Biological Treatment; SBR; High quality effluents; IPPC Directive; Best Available Techniques (BAT); Efford Landfill Site; Full-scale; Ammoniacal-N removal; COD removal; Methanogenic leachate; Reed bed

\section{INTRODUCTION}

The most common requirement at UK landfills is the reliable, robust, automated and costeffective treatment of typical strong leachates, where the main contaminants are ammoniacal nitrogen, and organic compounds determined as $\mathrm{COD}$ and $\mathrm{BOD}_{5}$.

Enviros Consulting, formerly known as Aspinwall \& Company, has successfully designed and commissioned more than 60 full-scale plants during the last 23 years, using Sequencing Batch Reactor (SBR) technology, with aerobic suspended growth treatment at the core of the process.

This paper describes a case study of the Efford Landfill Site leachate treatment plant that has been constructed and commissioned for Hampshire County Council at a large landfill in Southern England, using a traditional consultancy approach. The plant is operated on behalf of Hampshire County Council by Onyx Limited, operating as Hampshire Waste Services Ltd. The plant is a typical example of the sort of system presently being required by landfill operators.

An investigation into treatment efficiencies of the treatment process, which is capable of treating up to $150 \mathrm{~m}^{3} /$ day of strong methanogenic leachate from the operational landfill, is presented and compared with performances at other full-scale leachate treatment plants designed and commissioned by Enviros Consulting. The paper provides process descriptions, including fullscale techniques for readily achieving $\mathrm{BOD}_{5}$ and ammoniacal nitrogen removal efficiencies in excess of $99 \%$, as well as COD removal efficiencies in the order of 50 percent. The treatment plant at Efford provides polishing treatment in an $800 \mathrm{~m}^{2}$ reed bed.

\section{EFFORD LANDFILL}

Efford Landfill Site is located about $4 \mathrm{~km}$ south of Lymington, and $16 \mathrm{~km}$ due south of Lyndhurst in the New Forest, on the south coast of England. The site is within the South Hampshire Coast Area of Outstanding Natural Beauty.

Planning permission for the current gravel extraction and landfill operations at Efford was granted in 1982. In accordance with the UK landfill regulation requirements of the time, landfilling [in Phases 1, 2 and 3 (a) and (b)] was originally carried out on the 'dilute and disperse' principle. Since the introduction of revised standards in the early 1990s, new landfill site phases have been required to operate on a containment basis, and as a result Phases 3(c) and 4 at Efford are lined. The site is shown in plan in Figure 1. 


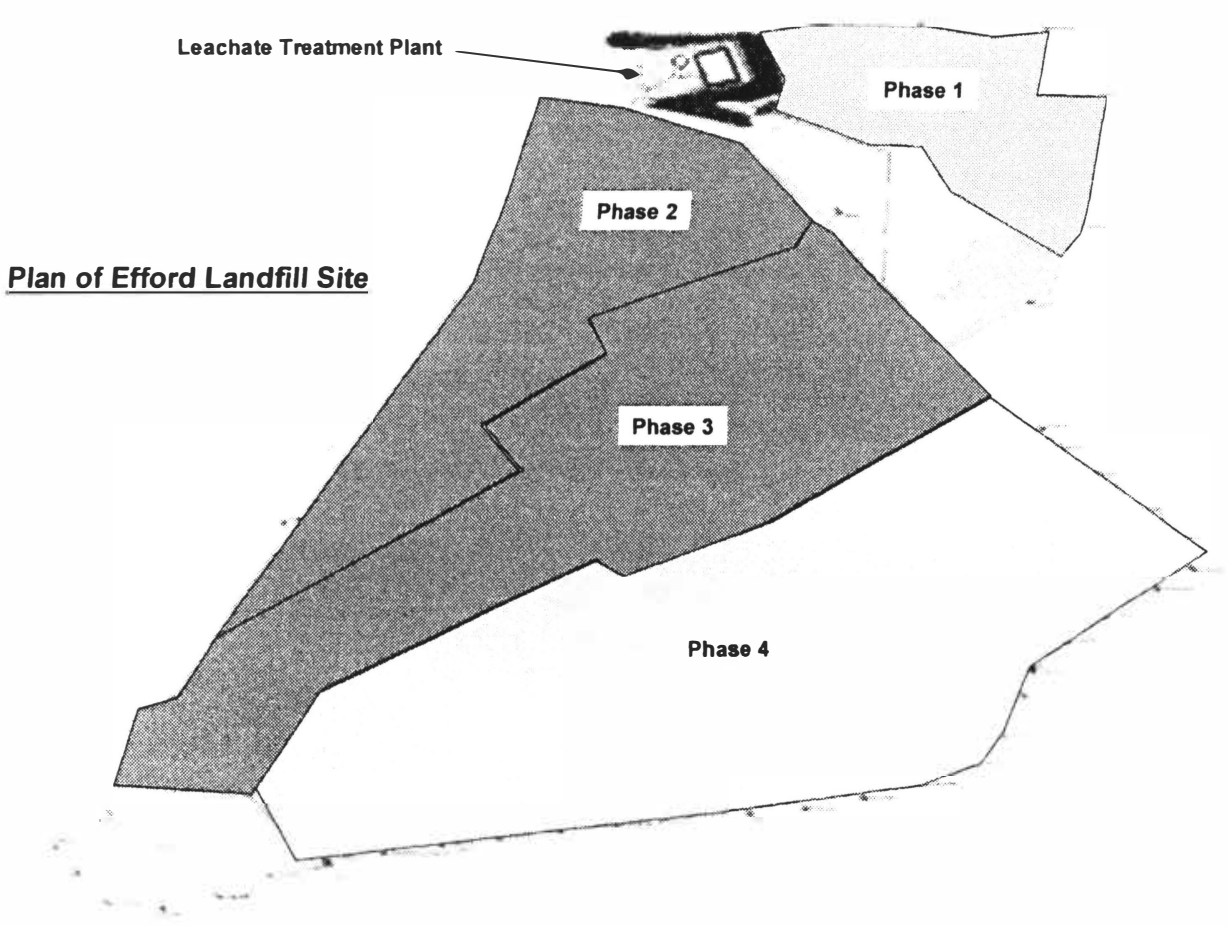

Figure 1. The site Map.

\section{TREATMENT REQUIRED}

The plant treats leachate from all 4 phases to comply with the Trade Effluent Discharge Consent before discharge into a Southern Water Plc sewer adjacent to the plant. Initially the plant was commissioned using leachate from only Phase 3, leachate from Phases 1, 2 and 4 has then been gradually introduced once the leachate extraction systems for these phases have been commissioned. Table 1 below presents typical characteristics of raw leachate from Phase 3 of the Efford Landfill Site, for comparison with the requirements of the Trade Effluent Discharge Consent.

As is the case for many other domestic landfill leachates, ammoniacal nitrogen is the primary constituent requiring treatment before discharge of effluent to public sewer. Treatment of organic compounds and suspended solids not only reduces the charges made by the sewerage provider 
(Southern Water plc) but also allows these discharges to be made to a relatively small local Sewage Treatment Works (STW). Effluent from this STW then discharges into the environmentally sensitive and high quality River Avon. This small rural STW would not have been capable of accepting a discharge of untreated leachate.

Table 1. Typical raw leachate characteristics from Efford Landfill Site Phase 3.

\begin{tabular}{|c|c|c|}
\hline Sample & Raw Leachate & Consented Discharge Limits \\
\hline Suspended solids & 238 & 400 \\
\hline COD & 798 & 2500 \\
\hline $\mathrm{BOD}_{20}$ & 124 & - \\
\hline $\mathrm{BOD}_{5}$ & 58 & - \\
\hline Ammoniacals $\mathrm{N}$ & 537 & 80 \\
\hline Alkalinity (as $\mathrm{CaCO}_{3}$ ) & 3550 & - \\
\hline Chloride & 1880 & 2000 \\
\hline Sulphate $\left(\mathrm{SO}_{4}\right)$ & 238 & 500 \\
\hline Phosphate (as P) & 24 & - \\
\hline $\mathrm{pH}$-value & 7.8 & $6<$ spH-value $<10$ \\
\hline Chromium & 0.014 & 0.25 \\
\hline Iron & 12.0 & - \\
\hline Nickel & 0.057 & 0.5 \\
\hline Copper & $<0.005$ & 0.5 \\
\hline Zinc & 0.039 & 1.5 \\
\hline Lead & 0.013 & 0.5 \\
\hline Arsenic & $<0.001$ & - \\
\hline Mercury & $<0 . \$ 001$ & - \\
\hline
\end{tabular}

\section{TREATMENT PROCESS}

The plant has been designed to achieve efficient nitrification. Nitrification is the biological oxidation of ammoniacal nitrogen to nitrate by autotrophic bacteria. The nitrification reaction is a two-stage oxidation, each stage being performed by a distinct group of bacteria. The first stage, oxidation of ammoniacal-N to nitrite, is performed by bacteria of the genus Nitrosomonas. The second stage, where this nitrite is further oxidised to nitrate, is performed by species of Nitrobacter. The reaction stages are shown below:

$$
\begin{array}{ll}
\text { 1st stage } & \mathrm{NH}_{4}^{+}+3 / 2 \mathrm{O}_{2} \rightarrow \mathrm{NO}_{2}^{-}+2 \mathrm{H}^{+}+\mathrm{H}_{2} \mathrm{O} \\
\text { 2nd stage } & \mathrm{NO}_{2}^{-}+1 / 2 \mathrm{O} \rightarrow \mathrm{NO}_{3}^{-} \\
\text {Overall } & \mathrm{NH}^{+}+2 \mathrm{O}_{2} \rightarrow \mathrm{NO}_{3}^{-}+2 \mathrm{H}^{+}+\mathrm{H}_{2} \mathrm{O}
\end{array}
$$


Both groups of bacteria are relatively sensitive (compared with those groups which oxidise organic substrates) to environmental conditions, and either one or both stages can be easily inhibited by:

- Low pH-values (below about 6.5);

- Insufficient dissolved oxygen (below about $2 \mathrm{mg} / \mathrm{l}$ );

- Low temperatures;

- Toxic inhibition.

The plant comprises a covered tank, with submersible venturi aerators, to ensure that temperatures within the treatment reactor remain at optimum values for nitrification at all times. The choice of a covered, thermally insulated reactor, was made to maintain temperatures at $15 \mathrm{SC}^{\mathrm{C}}$ or above, and thereby maximise treatment rates throughout winter months.

\section{EFFORD LEACHATE TREATMENT PLANT}

The Efford leachate treatment plant, shown in Figures 2 and 3, comprises a covered reinforced concrete raw leachate balance tank from which the raw leachate is pumped, into a covered reinforced concrete aeration tank (SBR) where the raw leachate and aerobic suspended growth microorganisms responsible for the treatment, are mixed and aerated using venturi aerators.

The treatment process is controlled by a programmable logic controller (PLC) which monitors and regulates the mixed liquor $\mathrm{pH}$-value. $\mathrm{pH}$-value correction is achieved automatically through alkali dosing. Dissolved oxygen and temperature of the liquor are monitored. A site specific Supervisory Control and Data Acquisition (SCADA) system provides the operator interface.

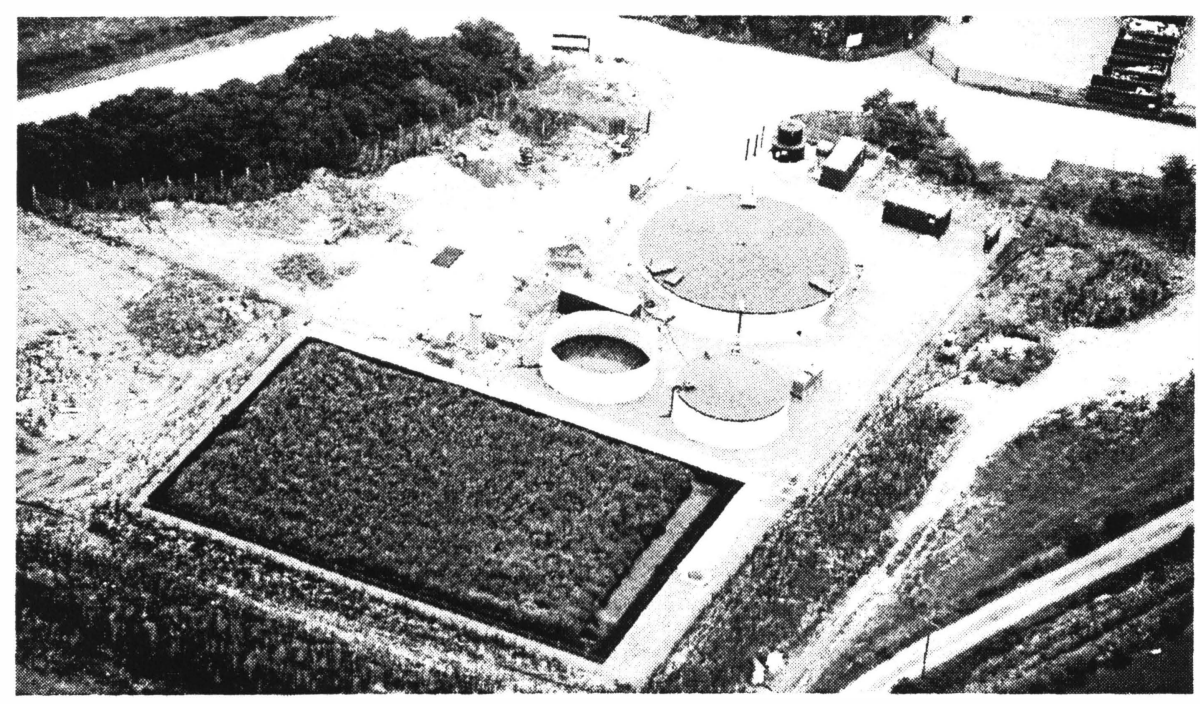

Figure 2. Efford Leachate Treatment Plant, from the North, 10 July 2003. 


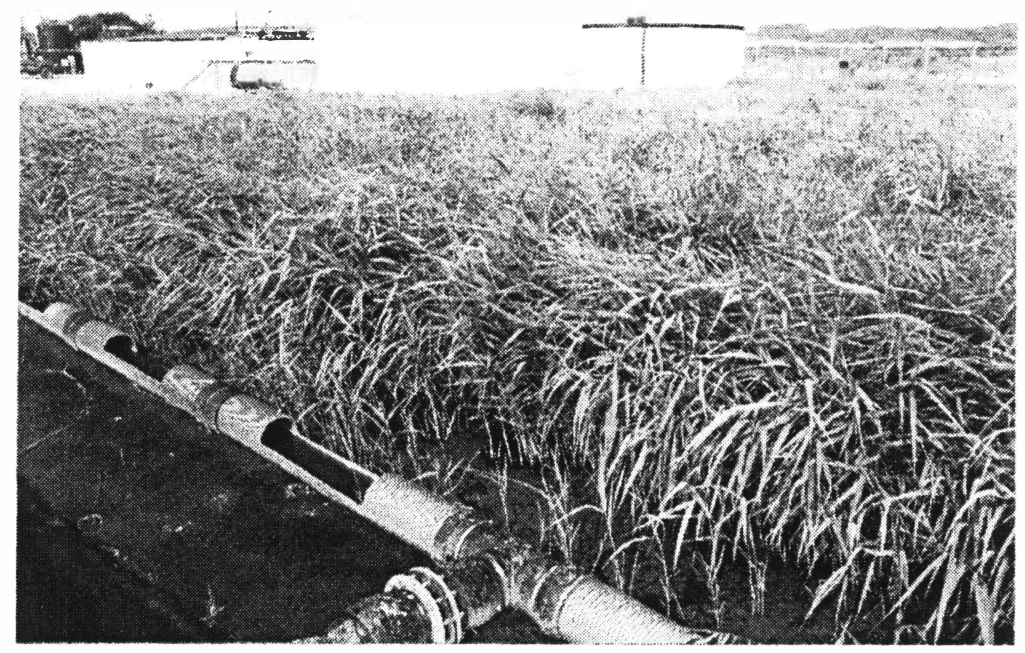

Figure 3. Efford Leachate Treatment Plant, view from the reed bed, 10 July 2003.

Treated leachate is decanted into an uncovered reinforced concrete balancing tank, from where it is allowed to flow by gravity into an $800 \mathrm{~m}^{2}$ subsurface flow reed bed, planted with Phragmites Australis reeds. The reed bed is used for polishing of the effluent prior to discharge to the Southern Water plc sewer.

The plant was procured by Hampshire County Council using a traditional consultancy route, Enviros preparing a very detailed design and specification, which was tendered to suitablyqualified contractors.

\section{PERFORMANCE OF THE LEACHATE TREATMENT PLANT}

Commissioning of the treatment plant started on 7 January 2003. The plant was seeded using a mixture of return activated sewage sludge and thickened sludge from an existing Enviros leachate treatment plant at Trecatti Landfill, near Merthyr Tydfil in South Wales. Treatment of leachate began directly after the plant was seeded.

\subsection{Volumes of leachate treated by the plant}

The volumes of leachate being treated - typically in the range $50-70 \mathrm{~m}^{3} / \mathrm{d}-$ are shown in Figure 4. 


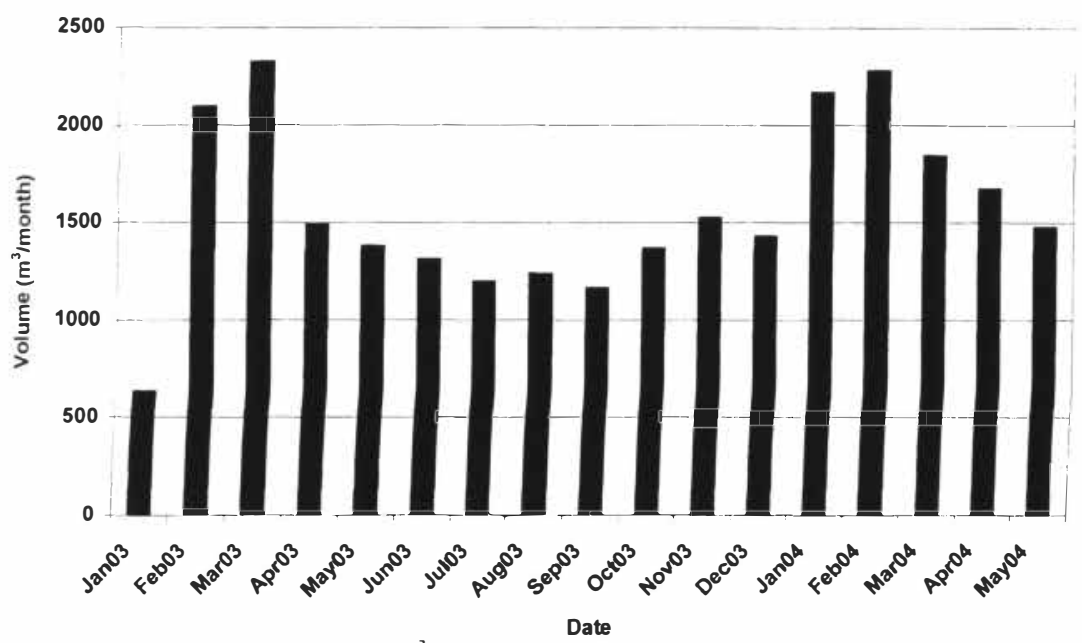

Figure 4. Monthly total volumes $\left(\mathrm{m}^{3}\right)$ of leachate treated by Efford LTP, January 2003 May 2004.

\subsection{Treatment of major contaminants}

The Efford plant rapidly settled down during commissioning, to treat the major contaminants present in the leachate effectively; organic compounds, ammoniacal nitrogen, and iron. Within four weeks of the start of biological commissioning, leachate was being treated at a rate in excess of $80 \mathrm{~m}^{3} / \mathrm{d}$, and subsequent treatment rates were constrained primarily by quantities of leachate that could be extracted from the landfill site.

The biological sludge effecting treatment began with a ratio of Volatile Suspended Solids to Total Suspended Solids (VSS to TSS) of about 0.5 to 0.6 , but as the biomass has acclimatised, this ratio has become very stable, remaining in the range 0.46 to 0.54 (mean $0.5 \mathrm{l}$ ) in thirteen samples of mixed liquor taken between 2 April and 30 June 2003.

\subsubsection{COD and $\mathrm{BOD}_{5}$ removal efficiencies}

COD values in treated effluent have always been comfortably below the consent limit of 2500 $\mathrm{mg} / \mathrm{l}$, and have always been below $400 \mathrm{mg} / \mathrm{l}$ in any final effluent sample, reducing trade effluent charges substantially, Figure 5.

The leachate treated during the first half of 2003, was all methanogenic leachate from the older part of the site (Phase 3), and this has meant that $\mathrm{BOD}_{5}$ values in incoming leachate, were low and were never above $172 \mathrm{mg} / \mathrm{l}$. These $\mathrm{BOD}_{5}$ values and higher values from younger leachates, seen later in the year and during 2004, have all been consistently reduced to below $5 \mathrm{mg} / \mathrm{l}$ in the final effluent. 
Kalmar ECO-TECH '05 and

The Second Baltic Symposium on Environmental Chemistry

KALMAR, SWEDEN, November 28-30, 2005

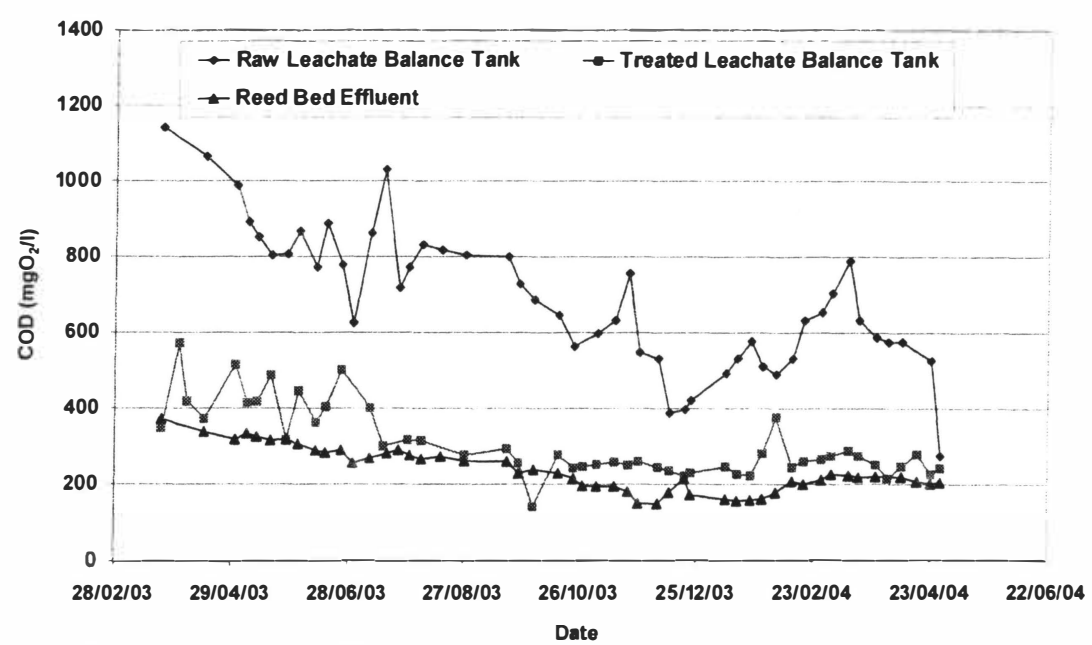

Figure 5. Removal of COD at Efford LTP, March 2003 - Mary 2004 (all results in mg/l).

\subsubsection{Ammoniacal nitrogen removal efficiencies}

Concentrations of ammoniacal nitrogen in effluent have also always been more than an order of magnitude less than the consent limit of $80 \mathrm{mg} / \mathrm{l}$, the highest single concentration being a value of $3.17 \mathrm{mg} / \mathrm{l}$ on 24 June 2003 (followed 6 days later by a result of $0.32 \mathrm{mg} / \mathrm{l}$ ).

Table 2. Mean values 2003, results for quality of leachate and of treated effluent for Efford LTP, Hampshire ( $\mathrm{mg} / \mathrm{l}$ exce $\mathrm{pt} \mathrm{pH}$-value)( - = no data).

\begin{tabular}{lccc}
\hline Determinand & Leachate & SBR effluent & Final effluent \\
\hline COD & 942 & 462 & 309 \\
BOD $_{5}$ & 72 & 22 & 3 \\
Ammoniacal-N & 820 & 1.59 & 0.48 \\
Alkalinity $\left(\mathrm{as} \mathrm{CaCO}_{3}\right)$ & 3830 & 1229 & 1138 \\
Nitrate-N & 0.21 & 423 & 384 \\
Nitrite-N & 0.04 & 0.56 & 0.87 \\
Chloride & 1502 & 1442 & 1507 \\
Suspended solids & - & - & 33 \\
pH-value & 7.6 & 8.2 & 8.4 \\
\hline
\end{tabular}

Figure 6 below summarises removal efficiencies achieved at Effiord during the six month period from January to 30 June 2003, and indicates the value of the reed bed polishing system in consistently reducing values of up to $5 \mathrm{mg} / \mathrm{l}$ in the SBR effluent to below $1 \mathrm{mg} / \mathrm{l}$. Overall removal of ammoniacal-N at Efford has been in excess of $99.9 \%$. 
Kalmar ECO-TECH '05 and

The Second Baltic Symposium on Environmental Chemistry

KALMAR, SWEDEN, November 28-30, 2005

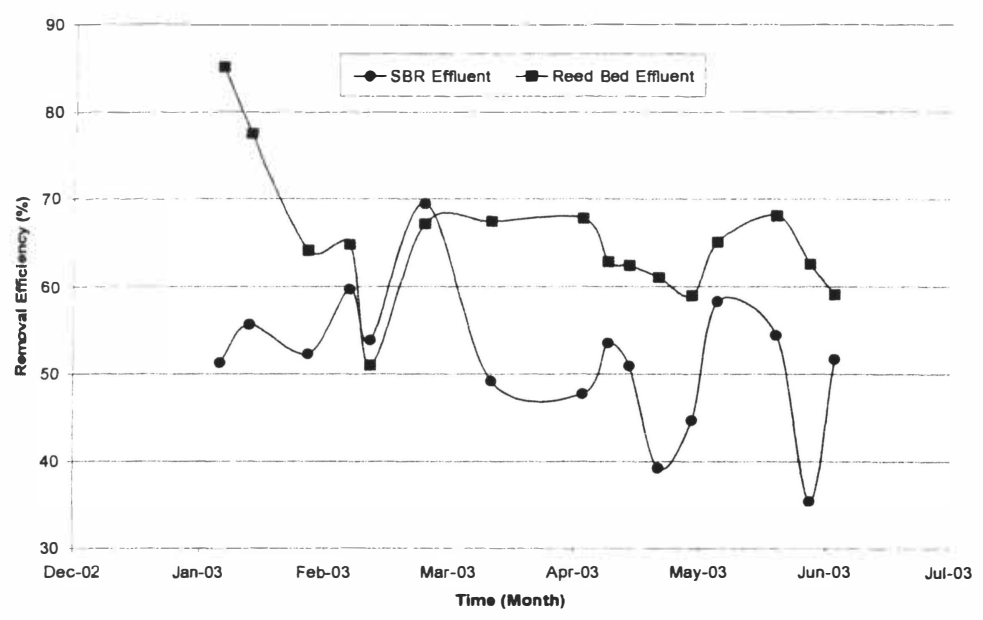

Figure 6. COD removal efficiencies achieved at Efford during the six-month period from January to June 2003. (These removal rate efficiencies are consistent with efficiencies reported in other recent research [1])

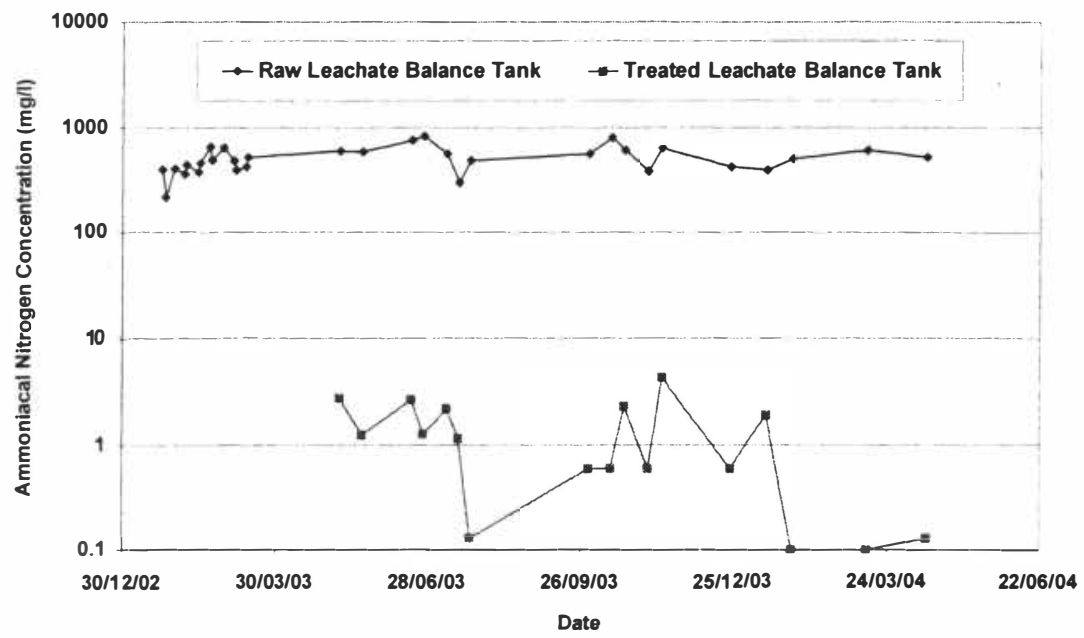

Figure 7. Removal of ammoniacal-N at Efford LTP, January 2003 - May 2004 (all results in mg/l as $N$ ). 


\subsubsection{Comparison with Similar SBR Systems}

In order to place COD and ammoniacal-N removal achieved by the Efford plant in the context of that achieved by other similar SBR systems, Table 3 presents real data from full-scale leachate treatment plants designed and commissioned by Enviros, and for a range of detailed pilot-scale leachate treatability trials carried out in our laboratory during the last few years.

Table 3. Data for effluent quality, in terms of $C O D$ and ammoniacal- $N$, when treating leachates similar to present and future leachates at Efford.

\begin{tabular}{|c|c|c|c|c|c|}
\hline \multirow{2}{*}{\multicolumn{2}{|c|}{ Site/Trial: }} & \multicolumn{2}{|c|}{ ammoniacal-N } & \multicolumn{2}{|c|}{ COD-value } \\
\hline & & influent & effluent & influent & effluens \\
\hline \multicolumn{6}{|c|}{ FULL-SCALE PLANTS: } \\
\hline Brookhill & & 1680 & 1.5 & 3000 & 1250 \\
\hline Llanddulas & & 1100 & $<0.1$ & 3600 & 910 \\
\hline Lord St. Helens & & 647 & $<0.1$ & 2010 & 564 \\
\hline Arthurstown & & 1000 & 1.0 & 2441 & 995 \\
\hline Arpley & & 1300 & 1.3 & 4570 & 1240 \\
\hline Deerplay & & 1410 & 4.7 & 2900 & 814 \\
\hline Whitehead & & 612 & 5.0 & 2969 & 503 \\
\hline \multicolumn{6}{|c|}{ PILOT-SCALE TRIALS: } \\
\hline & A & 853 & 0.5 & 1260 & 549 \\
\hline & B & 1130 & $<0.3$ & 7150 & 505 \\
\hline & $\mathrm{C}$ & 1110 & 1.4 & 2950 & 1070 \\
\hline & D & 1460 & 0.3 & 2620 & 1000 \\
\hline & E & 1330 & $<0.3$ & 2810 & 1310 \\
\hline & $\mathrm{F}$ & 773 & 0.5 & 1270 & 556 \\
\hline & G & 1150 & $<0.3$ & 2940 & 944 \\
\hline & $\mathrm{H}$ & 1190 & 1.2 & 1860 & 673 \\
\hline & I & 708 & 0.6 & 2350 & 318 \\
\hline & $\mathrm{J}$ & 644 & $<0.3$ & 1030 & 470 \\
\hline & $\mathrm{K}$ & 1282 & 0.8 & 3444 & 1150 \\
\hline & $\mathrm{L}$ & 847 & 0.5 & 1875 & 758 \\
\hline & M & 974 & 0.5 & 2225 & 1007 \\
\hline & $\mathrm{N}$ & 1156 & 1.7 & 873 & 684 \\
\hline
\end{tabular}

Notes: 1. Full-scale plants; data represent spot samples taken at these sites as part of a large research contract. (All plants designed and commissioned by Enviros).

2. Pilot-scale trials; represent data from detailed leachate treatability trials undertaken by Enviros. The names of the relevant landfill, sites have been omitted for confidentiality reasons.

3. All results expressed in $\mathrm{mg} / \mathrm{l}$. 


\author{
Kalmar ECO-TECH'05 and \\ The Second Baltic Symposium on Environmental Chemistry \\ KALMAR, SWEDEN, November 28-30, 2005
}

These data from our database have been selected, because they represent the extent of treatment that can reasonably be expected for raw leachates similar in composition to those presently being treated at Efford, and likely to be treated in future - as stronger leachates from more recent phases of the Efford landfill site are blended into incoming leachates.

\title{
8 CONCLUSIONS
}

Experiences at Effiord Landfill leachate treatment plant, and at a large number of treatment plants designed and commissioned by Enviros Consulting, have demonstrated that there are no technical barriers to the treatment of landfill leachate to high standards, using systems that meet the requirements of Best Available Techniques.

Process designs based on scientific facts, pilot scale research and extensive experience in leachate treatment, together with sound engineering practice, are the key elements in ensuring that the process conditions and environment are maintained in a full scale leachate treatment plant to provide a reliable, robust, automated and cost-effective system.

\section{ACKNOWLEDGEMENTS}

The authors wish to thank the staff of the Hampshire County Council, and of Onyx Hampshire Limited who assisted in collecting the data, and making it available. These include Ross Mackenzie and Clare Saunders, of Hampshire CC, plus Mike Banner and Hailey Tamblyn of Onyx.

\section{REFERENCES}

[1] Carville, M.S., Last, S.D., Olufsen, J.S. Robinson, H.D., 2003. Characterisation of contaminant removal achieved by biological leachate treatment systems. Paper presented to Sardinia 2003, the Ninth International Waste Management and Landfill Symposium, S. Margherita di Pula, Cagliari, Italy, 6-10 October 2003, Proceedings on CD, 11 pp.

[2] Robinson, H.D., Olufsen, J., Last, S., 2005. Design and operation of cost-effective leachate treatment schemes at UK landfills: Recent case studies. Paper presented to the 2004 Annual Conference and Exhibition of the Chartered Institute of Wastes Management, 15-18 June 2004, Paignton, Torbay, UK. Landfill Workshop, 16 June 2004. Published in the Scientific and Technical Review Journal, CIWM, April 2005, 6, (1), 14-24. 